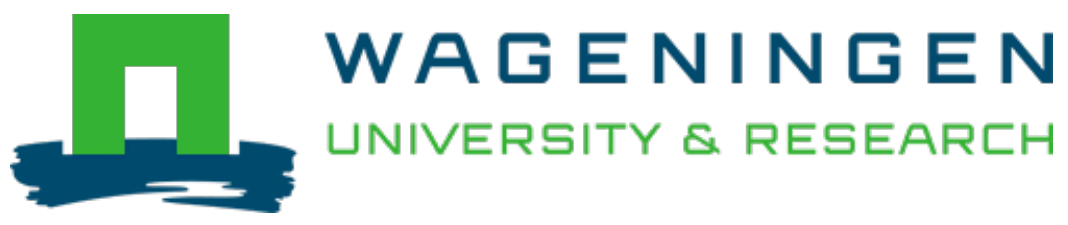

\title{
Nutritive value of masau (Ziziphus mauritiana) fruits from Zambezi Valley in Zimbabwe
}

\author{
Food Chemistry \\ Nyanga, L.K.; Gadaga, T.H.; Nout, M.J.R.; Smid, E.J.; Boekhout, T. et al \\ https://doi.org/10.1016/j.foodchem.2012.10.016
}

This publication is made publicly available in the institutional repository of Wageningen University and Research, under the terms of article $25 \mathrm{fa}$ of the Dutch Copyright Act, also known as the Amendment Taverne. This has been done with explicit consent by the author.

Article 25 fa states that the author of a short scientific work funded either wholly or partially by Dutch public funds is entitled to make that work publicly available for no consideration following a reasonable period of time after the work was first published, provided that clear reference is made to the source of the first publication of the work.

This publication is distributed under The Association of Universities in the Netherlands (VSNU) 'Article $25 \mathrm{fa}$ implementation' project. In this project research outputs of researchers employed by Dutch Universities that comply with the legal requirements of Article $25 \mathrm{fa}$ of the Dutch Copyright Act are distributed online and free of cost or other barriers in institutional repositories. Research outputs are distributed six months after their first online publication in the original published version and with proper attribution to the source of the original publication.

You are permitted to download and use the publication for personal purposes. All rights remain with the author(s) and / or copyright owner(s) of this work. Any use of the publication or parts of it other than authorised under article $25 \mathrm{fa}$ of the Dutch Copyright act is prohibited. Wageningen University \& Research and the author(s) of this publication shall not be held responsible or liable for any damages resulting from your (re)use of this publication.

For questions regarding the public availability of this publication please contact openscience.library@wur.nl 


\title{
Nutritive value of masau (Ziziphus mauritiana) fruits from Zambezi Valley in Zimbabwe
}

\author{
Loveness K. Nyanga $^{\mathrm{a}, \mathrm{c}}$, Tendekayi H. Gadaga ${ }^{\mathrm{b}}$, Martinus J.R. Nout ${ }^{\mathrm{c}}$, Eddy J. Smid ${ }^{\mathrm{c}, *}$, Teun Boekhout ${ }^{\mathrm{d}}$, \\ Marcel H. Zwietering ${ }^{c}$
}

${ }^{a}$ Institute of Food, Nutrition and Family Sciences, University of Zimbabwe, Harare, Zimbabwe

${ }^{\mathrm{b}}$ Department of Environmental Health Science, Faculty of Health Sciences, University of Swaziland, Mbabane, Swaziland

${ }^{\mathrm{c}}$ Laboratory of Food Microbiology, Wageningen University, The Netherlands

${ }^{\mathrm{d}}$ CBS-KNAW Fungal Biodiversity Centre, Utrecht, The Netherlands

\section{A R T I C L E I N F O}

\section{Article history:}

Received 13 June 2012

Received in revised form 11 October 2012

Accepted 16 October 2012

Available online 5 November 2012

\section{Keywords:}

Masau fruits

Proximate composition

Micronutrient potential

\begin{abstract}
A B S T R A C T
Ziziphus mauritiana (masau) fruits are consumed by many people in Zimbabwe. The fruits contribute significantly to people's diet when they are in season. The objective of this study was to determine the nutritional content of the fruits and, hence, quantify their contribution to the diet. Samples of masau were collected in two seasons (August 2006 and August 2007). Both macronutrients and micronutrients were determined using standard AOAC methods of analysis. Dry matter content ranged from $21.1 \pm 0.2$ to

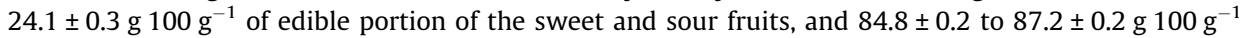
for the dried fruit. Crude protein per $100 \mathrm{~g}$ edible portion of dry weight ranged between $7.9 \pm 0.0$ and $8.7 \pm 0.0 \mathrm{~g}$, crude fat from $0.8 \pm 0.0$ to $1.5 \pm 0.0 \mathrm{~g}$, crude fibre from $4.9 \pm 0.0$ to $7.3 \pm 0.0 \mathrm{~g}$, ash between $3.0 \pm 0.0$ and $4.3 \pm 0.0 \mathrm{~g}$ and carbohydrate between $79.5 \pm 0.0$ and $83.2 \pm 0.0 \mathrm{~g}$. The fruits were rich in vita$\min C\left(15.0 \pm 0.0-43.8 \pm 0.02 \mathrm{mg} 100 \mathrm{~g}^{-1}\right)$ and the energy values ranged between $1516.0 \pm 1.73$ and

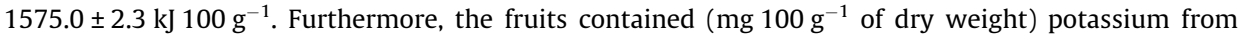
$1865.0 \pm 1.3$ to $2441.0 \pm 1.1$, calcium from $160.0 \pm 0.3$ to $254.0 \pm 0.1$, sodium between $185.0 \pm 0.1$ and $223.0 \pm 0.2$, magnesium between $83.0 \pm 0.0$ and $150.0 \pm 0.13$ and phosphorous from $87.0 \pm 0.1$ to $148.0 \pm 0.5$. Manganese and copper contents ranged between $0.7 \pm 0.03$ and $1.6 \pm 0.03$, while iron and zinc ranged between $2.1 \pm 0.43$ and $4.3 \pm 0.1$, and $0.6 \pm 0.0-0.9 \pm 0.0 \mathrm{mg} 100 \mathrm{~g}^{-1}$ of dry weight, respectively. The masau fruit is therefore a good potential source of carbohydrates, proteins and micronutrients, such as calcium, potassium, sodium, phosphorous, copper, iron, Vitamin C and zinc.
\end{abstract}

(C) 2012 Elsevier Ltd. All rights reserved.

\section{Introduction}

Indigenous fruits are essential for food security, health and nutrition, and economic welfare of rural communities in the developing world (Saka, Rapp, Akinnifesi, Ndolo, \& Mhango, 2007). Ziziphus mauritiana (Rhamnaceae), Sclerocarya birrea (Anacardiaceae), Uapaca kirkiana (Phyllanthaceae), Strychnos cocculoides (Loganiaceae) and Adansonia digitata (Bombaceae) are amongst the commonly utilised indigenous fruits in Africa.

In Zimbabwe, the collecting, processing, storing and marketing of indigenous fruits are notable coping strategies adopted by rural communities to reduce hunger, improve nutrition and generate income (Mithofer, Waibel, \& Akinnifesi, 2006). Z. mauritiana fruits, locally called masau in the Shona language, are extensively gathered, processed and marketed (Nyanga, Nout, Gadaga, Boekhout, \& Zwietering, 2008). Masau fruits ripen from mid-June and are

\footnotetext{
* Corresponding author. Tel.: +31 3174828 34; fax: +31 317484978 .

E-mail address: eddy.smid@wur.nl (E.J. Smid).
}

available until the end of September. Although the trees can grow in many different parts of the country, they normally grow and fruit in warmer climates as is found in the low lying areas of the Zambezi valley. Rural communities in Zimbabwe distinguish the fruits into sour and sweet categories (Nyanga et al., 2008). The fruit is first green, turning yellow to brown as it ripens, and it is generally considered to have a sweet-sour taste. Fruit sizes range from 1 to $3 \mathrm{~cm}$ in diameter.

Some research has been done in Zimbabwe to improve the postharvest quality of the masau fruit (Tembo, Chiteka, Kadzere, Akinnifesi, \& Tagwira, 2008), and on the traditional processing of the fruit (Nyanga et al., 2008). Microorganisms, such as lactic acid bacteria and yeasts, have been isolated from the fruits and were identified (Nyanga et al., 2007). Other studies have shown that these fruits are potentially a rich source of vitamin $C$ and minerals (Morton, 1987). Rathore (2009) also reported that Z. mauritiana fruits was richer than apple in protein, phosphorus, calcium and vitamin C, and contained more phosphorus, iron, vitamin C, calorific value and carbohydrates than oranges. However, a great 
variation has been recorded in the fruit's nutritional content depending on the source and/or cultivar of the fruit. Although the fruit is widely sold at rural and urban markets, information on the nutritional content of the masau fruits found in Zimbabwe is scarce. Availability of nutritional data can improve the perception of the fruit, which is usually considered as a poor man's fruit. The aim of the current study, therefore, was to determine the nutritional value of masau fruits obtained in Zimbabwe over a period of two seasons. The information will be a useful guide in nutrition assessments because the fruits are an important part of the diet in some rural and urban communities in Zimbabwe, and will aid in marketing efforts, so as to improve the livelihood of rural families.

\section{Materials and methods}

\subsection{Sampling and processing}

Mature, fresh, sour, and sweet masau fruits were procured from villages in Muzarabani $\left(16^{\circ} 20^{\prime} \mathrm{S}, 31^{\circ} 21^{\prime} \mathrm{E}\right)$ rural community in 2006 and 2007, in the month of August when the masau fruits are in season. The fruits were taken from fruit trees in fields belonging to certain households identified by the village extension officer. The same households were visited for each sampling trip. Samples of the dried masau fruit were obtained from the same households. Fruits collected from different villages were put into three categories; i.e. sweet fresh, sour fresh and sour dried. Ten samples were collected for each category of fruits per season. The fruits were packed in polyethylene bags and transported in a cooler box to the laboratory at the University of Zimbabwe. The fruits were kept overnight at $4{ }^{\circ} \mathrm{C}$ and processed the following day. The fruits were washed with distilled water before analysis. The fruits from each category from the same year were pooled to make a composite sample of $1 \mathrm{~kg}$. Composite samples of each fruit category were made to get a representative sample of what the rural and urban people consume. The fruits are usually gathered from different areas and trees to fill up 10-20 kg buckets and are transported home, to the rural markets, or as truck loads to the urban markets. The fruits were sorted based on quality and size. Mature, unblemished fruits were used for analysis. For the fresh fruits, 10-15 fruits $(100 \mathrm{~g})$ from each of the 10 collected samples were taken for processing and $40-50$ fruits $(100 \mathrm{~g})$ for the dried samples. The seeds were carefully removed by knife from pulp and skin, which were then homogenised using a Waring blender. The samples were stored at $4{ }^{\circ} \mathrm{C}$ until required for analysis. All analyses were done in triplicate.

\subsection{Chemical analysis}

\subsubsection{Determination of proximate composition}

The homogenised fruit samples were analysed for dry matter, ash, crude fibre, fat, and crude protein according to the AOAC (1990) official methods. Briefly, dry matter was determined by drying a portion $(2 \mathrm{~g}$ ) from the composite sample for each year to constant weight in an oven at $105^{\circ} \mathrm{C}$. Ash was determined by incinerating the dried sample $(2 \mathrm{~g})$ in a muffle furnace at $600{ }^{\circ} \mathrm{C}$ for $6 \mathrm{~h}$. Crude protein was estimated by the macro-Kjeldahl method, and calculated by multiplying the measured nitrogen by 6.25 (method 978.04, AOAC, 1990). An aliquot of $3 \mathrm{~g}$ was used to determine crude fat by extracting with petroleum ether $\left(40-60^{\circ} \mathrm{C}\right)$ in a Soxhlet apparatus. The crude fibre was determined by alternately digesting the dried, defatted sample $(2 \mathrm{~g})$ in $1.25 \% \mathrm{HCl}$ and $1.25 \%$ $\mathrm{NaOH}$ (method 930.10, AOAC, 1990). The digested sample was then ashed in a muffle furnace at $600{ }^{\circ} \mathrm{C}$. The crude fibre was then expressed as percent weight loss on ignition at the ashing tempera- ture. Carbohydrate levels were calculated by subtracting the total sum of crude protein, crude fat, and crude fibre from $100 \%$ dry weight sample. The fruit calorific value (expressed in $\mathrm{kJ}$ ) was estimated by multiplying the percentages of crude protein, crude fat and carbohydrate by the factors $16.7,37.7$ and 16.7 respectively (AOAC, 1990).

\subsubsection{Determination of vitamin $C$}

Vitamin $C$ was estimated by titration with 2,6-dichlorophenolindophenol (DCPIP, 0.05\%, w/v, Sigma-Aldrich Chemie, Steinheim, Germany) (Paul \& Pearson, 1967). Briefly, the fruit juice made from a portion of the homogenised composite sample was diluted with an equal volume of $1 \%$ oxalic acid (Merck, Damstardt, Germany). To $10 \mathrm{ml}$ of the diluted juice, acetone $(2.5 \mathrm{ml})$ was added and the mixture was allowed to stand for 10 min in the dark. The mixture was then titrated with DCPIP solution until a weak pink colour was observed.

\subsubsection{Determination of mineral content}

Potassium and sodium were determined by a method described by Bonire, Jahil, and Lori (1990). The ash of the pulp (0.5 g) was digested by adding a mixture of perchloric acid $(60 \%, 1 \mathrm{ml})$, nitric acid $(70 \%, 5 \mathrm{ml})$ and sulphuric acid $(98 \%, 0.5 \mathrm{ml})$ in a Kjeldahl flask. The digestion was begun at low heat with swirling until evolution of brown fumes subsided, and continued at steadily increasing temperatures controlling the rest of digestion until the solid was dissolved. After cooling, the digest was made up to $100 \mathrm{ml}$ with distilled water. Sodium and potassium were then determined using flame emission (FAAES, SHIMADZU Corporation, AA 6406 series). Calcium, magnesium, iron, zinc, copper and manganese were determined using atomic absorption spectroscopy according to the AOAC method 968.08 (1990). The sample was prepared in a similar way to that of sodium and potassium above. In order to avoid phosphate and ionisation interferences, an additional 1/10 $(\mathrm{v} / \mathrm{v})$ dilution was performed in lanthanum chloride $(1.8 \%, \mathrm{w} / \mathrm{v})$ for determination of calcium and magnesium. Sample concentrations of each element were determined by comparing absorbance to a standard linear regression curve from standard solutions. Phosphorus was determined using a Scanning UV-VIS-NIR Spectrophotometer (UV-3101PC, SHIMADZU Corporation, Japan) according to the method described by Lazano-Calero, MartinPalomeque, and Madueno-Loriguillo (1996). Standards for the minerals ( $\mathrm{Ca}, \mathrm{Mg}, \mathrm{K}, \mathrm{Na}, \mathrm{P}, \mathrm{Fe}, \mathrm{Cu}, \mathrm{Mn}$ and $\mathrm{Zn}$ ) and other reagents (perchloric acid, nitric acid, sulphuric acid and lanthanum chloride) were obtained from ALDRICH Co. (Sigma-Aldrich Chemie, Steinheim, Germany).

\subsection{Statistical analysis}

One way analysis of variance (ANOVA) was used to compare means of samples of the masau fruit categories (i.e. sweet fresh, sour fresh and sour dried) and between the two years. Least Significant Difference (LSD) was used to identify significant differences at $\alpha=0.05$ levels using Statistical Package for Social Sciences (SPSSs) version 16

\section{Results and discussion}

\subsection{Proximate and vitamin $C$ composition}

Dry matter, moisture, carbohydrate, crude protein, crude fat and fibre, vitamin C and energy content of masau fruits gathered during two consecutive years, 2006 and 2007, were analysed. The proximate and vitamin $\mathrm{C}$ composition of the fruits are presented in Table 1 . While the dry matter content and vitamin 
Table 1

Nutrient composition of masau fruits from Muzarabani rural community in Zimbabwe.

\begin{tabular}{|c|c|c|c|c|c|c|c|c|}
\hline Masau fruit & Dry matter ${ }^{*}(\mathrm{~g})$ & Ash (g) & Crude protein $(\mathrm{g})$ & Crude fat (g) & Crude fibre (g) & Carbohydrate $^{* *}(\mathrm{~g})$ & Energy value (kJ) & Vitamin $C^{*} \mathrm{mg}$ \\
\hline \multicolumn{9}{|l|}{ Sour } \\
\hline 2006 & $24.1 \pm 0.3^{\mathrm{a}}$ & $3.6 \pm 0.1^{\mathrm{a}}$ & $8.0 \pm 0.1^{\mathrm{a}}$ & $1.5 \pm 0.0^{\mathrm{a}}$ & $5.3 \pm 0.0^{\mathrm{a}}$ & $79.5 \pm 0.0^{\mathrm{a}}$ & $1517.0 \pm 1.2^{\mathrm{a}}$ & $28.6 \pm 0.8^{\mathrm{a}}$ \\
\hline 2007 & $21.1 \pm 0.2^{\mathrm{a}}$ & $3.1 \pm 0.0^{\mathrm{b}}$ & $7.9 \pm 0.0^{\mathrm{a}}$ & $1.5 \pm 0.0^{\mathrm{a}}$ & $5.2 \pm 0.0^{\mathrm{a}}$ & $79.6 \pm 0.0^{\mathrm{a}}$ & $1516.0 \pm 1.7^{\mathrm{a}}$ & $27.8 \pm 0.2^{\mathrm{a}}$ \\
\hline \multicolumn{9}{|l|}{ Sweet } \\
\hline 2006 & $23.2 \pm 0.2^{\mathrm{a}}$ & $3.0 \pm 0.0^{\mathrm{b}}$ & $8.7 \pm 0.0^{\mathrm{b}}$ & $1.5 \pm 0.0^{\mathrm{a}}$ & $7.3 \pm 0.0^{\mathrm{b}}$ & $81.7 \pm 0.0^{\mathrm{b}}$ & $1566.0 \pm 2.3^{\mathrm{a}}$ & $43.8 \pm 0.0^{\mathrm{b}}$ \\
\hline 2007 & $22.5 \pm 0.3^{\mathrm{a}}$ & $3.1 \pm 0.0^{\mathrm{b}}$ & $8.6 \pm 0.0^{\mathrm{b}}$ & $1.5 \pm 0.0^{\mathrm{a}}$ & $7.3 \pm 0.0^{\mathrm{b}}$ & $82.3 \pm 0.0^{\mathrm{b}}$ & $1575.0 \pm 2.4^{\mathrm{a}}$ & $40.7 \pm 0.0^{\mathrm{b}}$ \\
\hline \multicolumn{9}{|l|}{ Sour-dried } \\
\hline 2006 & $87.2 \pm 0.2^{c}$ & $4.3 \pm 0.0^{\mathrm{a}}$ & $7.9 \pm 0.0^{\mathrm{a}}$ & $0.8 \pm 0.0^{\mathrm{b}}$ & $4.9 \pm 0.0^{\mathrm{a}}$ & $82.1 \pm 0.0^{\mathrm{b}}$ & $1535.0 \pm 1.4^{\mathrm{a}}$ & $18.2 \pm 0.1^{\mathrm{c}}$ \\
\hline 2007 & $84.8 \pm 0.2^{c}$ & $3.1 \pm 0.0^{\mathrm{b}}$ & $7.9 \pm 0.0^{\mathrm{a}}$ & $0.8 \pm 0.0^{\mathrm{b}}$ & $5.0 \pm 0.0^{\mathrm{a}}$ & $83.2 \pm 0.0^{\mathrm{b}}$ & $1550.0 \pm 1.3^{\mathrm{a}}$ & $15.0 \pm 0.2^{c}$ \\
\hline
\end{tabular}

* Dry matter and Vitamin C based on $100 \mathrm{~g}$ fresh weight, all other parameters based on $100 \mathrm{~g}$ dry weight.

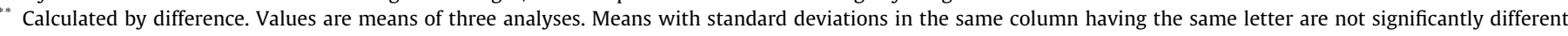
$(p<0.05)$.

C were determined on a fresh weight basis, all the other parameters were based on dry weight. Overall, there was no significant variation $(p<0.05)$ in the proximate composition among samples in the same category collected in the 2006 and 2007 seasons. The major components of the fruit were moisture and carbohydrates. The moisture content of the fresh fruits ranged from $75.9 \pm 0.32$

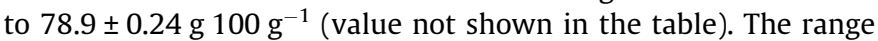
of the moisture content of the fruit was similar to that of the conventional fruits which ranges between 75\% and 95\% (Ruiz-Rodríguez et al., 2011).

Dry matter content of fresh sweet and fresh sour fruits ranged

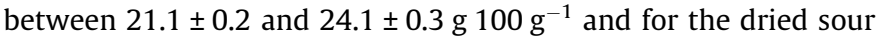

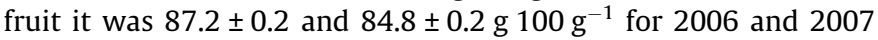
seasons, respectively. The dry matter contents which are

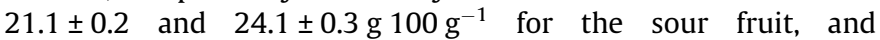

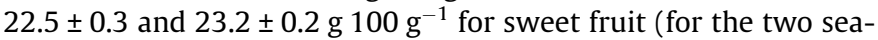

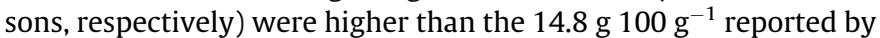
Saka and Msonthi (1994) from Z. mauritiana fruits from Malawi. This is probably due to different environmental conditions, such as water availability, sunlight and wind exposure which contribute to fruit desiccation (Ruiz-Rodríguez et al., 2011). However, the dry matter values are similar to those of other edible wild fruits such as Strychnos innocua and Strychnos spinosa, with values of 21.8 and

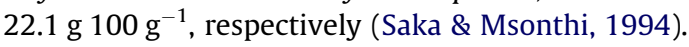

The ash content ranged between $3.0 \pm 0.0$ and

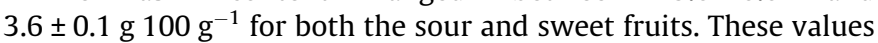
are similar to those reported by Lockett, Calvet, and Grivetti (2000). In that particular study, Z. mauritiana from Nigeria was found to

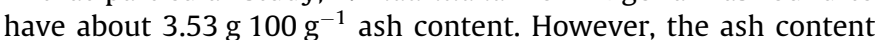
values in the current study were lower than the $10.1{\mathrm{~g} 100 \mathrm{~g}^{-1} \text { re- }}^{-}$ ported by Saka and Msonthi (1994).

The masau fruit had a crude protein ranging between $8.0 \pm 0.1$

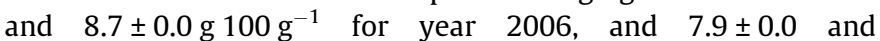

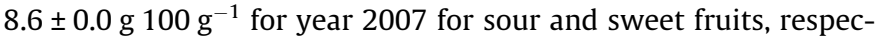
tively. The crude protein contents for the sour fruits were similar

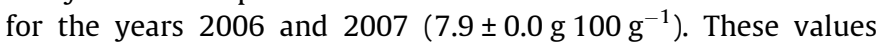
are relatively high considering that fruits are generally not good sources of protein (Agrahar-Murugkar \& Subbulakshmi, 2005).

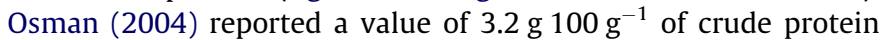
for baobab fruit pulp. Other wild edible fruits, namely A. digitata, S. birrea, S. spinosa and Vanguenia infausta from Botswana were reported to have crude protein contents ranging from 1.3 to

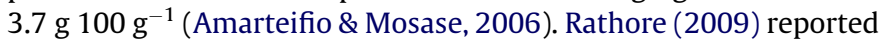
that fruits such as orange, mango, grapes, banana and papaya have crude protein contents of $0.7,0.6,0.5,1.2$ and 0.6 , respectively. Fresh sweet masau fruit contained significantly $(p<0.05)$ more

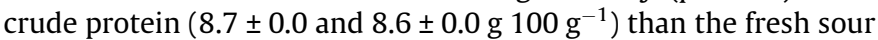

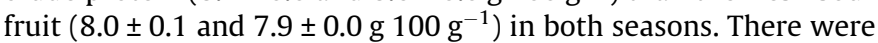
no significant differences $(p>0.05)$ in the crude protein contents between seasons for each category of masau fruit. The crude protein values recorded for sweet and sour masau fruits were much

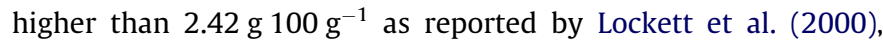
$4.1{\mathrm{~g} 100 \mathrm{~g}^{-1}}^{-1}$ reported by Saka and Msonthi (1994) and

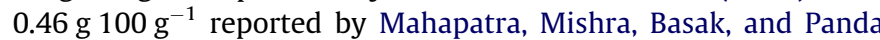
(2012) for Z. mauritiana from other regions.

The crude fat content ranged from $0.8 \pm 0.0$ to

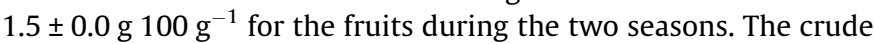

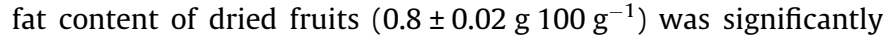
$(p<0.05)$ lower than the contents $(1.5 \pm 0.0$ and $1.5 \pm 0.0 \mathrm{~g}$ $100 \mathrm{~g}^{-1}$ ) found in both fresh sweet and fresh sour fruits. The lower value in the dried fruit could be attributed to some degradation of the lipids during drying (Lewicki, 1998).

The sweet fruits had significantly higher amounts of crude fibre

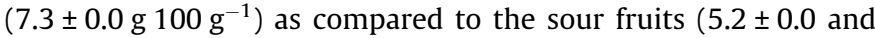

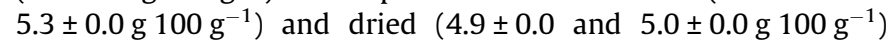
fruits. The levels of crude fibre in the masau fruits in this study

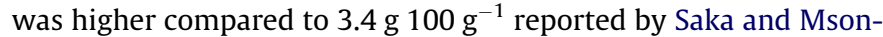
thi (1994).

The masau fruits were rich in carbohydrates and the values ran-

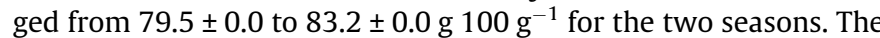
carbohydrate values were similar among the samples studied. Lockett et al. (2000) reported a lower carbohydrate value of

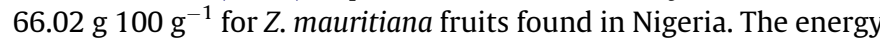

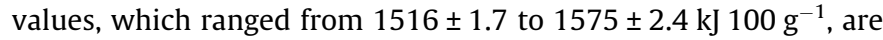
indicative of the high carbohydrate content. In another study, Saka and Msonthi (1994) reported a similar energy value of $1588 \mathrm{~kJ} 100 \mathrm{~g}^{-1}$.

The vitamin $C$ content was found to be highest in sweet fruit

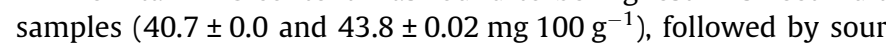
fruits $\left(27.8 \pm 0.2\right.$ and $\left.28.6 \pm 0.8 \mathrm{mg} 100 \mathrm{~g}^{-1}\right)$ and the lowest amount was found in dried fruits $\left(15.0 \pm 0.2\right.$ and $\left.18.2 \pm 0.1 \mathrm{mg} 100 \mathrm{~g}^{-1}\right)$. There were significant differences $(p<0.05)$ in vitamin $C$ content among the sweet, sour and dried samples. The difference in vitamin $C$ content among the sweet and sour fruits samples can probably be due to the fact that the sweet masau fruit trees are found mainly along river banks which are cooler than the drier areas where the sour masau fruit trees are located. Naggy (1980) reported that vitamin $\mathrm{C}$ content in fruits is affected by production factors, environmental conditions, maturity state and position on the tree, type of fruits (species and variety), handling and storage. As expected, the dried sour fruits had low vitamin $C$ content. Tembo et al. (2008) also showed that the vitamin $C$ content in masau fruits was negatively affected by drying. Moreover, temperature and duration of storage have also been reported to affect vitamin C content in masau fruits (Tembo et al., 2008). The vitamin C contents obtained in this study, however, were lower than the values (65.8-76 mg $100 \mathrm{~g}^{-1}$ ) reported in fruits from India, and those from semi-arid lowlands in West Africa (96-500 mg $100 \mathrm{~g}^{-1}$ ) 
Table 2

Mineral content in masau fruits from Muzarabani rural community in Zimbabwe.

\begin{tabular}{|c|c|c|c|c|c|c|c|c|c|}
\hline \multirow[t]{2}{*}{ Masau fruits } & \multicolumn{9}{|c|}{ Minerals $\left(\mathrm{mg} 100 \mathrm{~g}^{-1}\right)^{*}$} \\
\hline & $\mathrm{Ca}$ & $\mathrm{Mg}$ & K & $\mathrm{Na}$ & $\mathrm{P}$ & $\mathrm{Fe}$ & $\mathrm{Cu}$ & Mn & $\mathrm{Zn}$ \\
\hline \multicolumn{10}{|l|}{ Sour } \\
\hline 2006 & $238.0 \pm 0.1^{\mathrm{a}}$ & $92.0 \pm 0.1^{\mathrm{a}}$ & $2133.0 \pm 1.4^{\mathrm{a}}$ & $198.0 \pm 0.5^{\mathrm{a}}$ & $145.0 \pm 0.2^{\mathrm{a}}$ & $2.1 \pm 0.5^{\mathrm{a}}$ & $0.9 \pm 0.4^{\mathrm{a}}$ & $1.6 \pm 0.0^{\mathrm{a}}$ & $0.6 \pm 0.0^{\mathrm{a}}$ \\
\hline 2007 & $248.0 \pm 0.2^{\mathrm{b}}$ & $90.0 \pm 0.1^{\mathrm{a}}$ & $2317.0 \pm 1.2^{\mathrm{b}}$ & $185.0 \pm 0.1^{b}$ & $148.0 \pm 0.5^{\mathrm{a}}$ & $2.1 \pm 0.4^{\mathrm{a}}$ & $1.0 \pm 0.2^{\mathrm{a}}$ & $1.5 \pm 0.0^{\mathrm{a}}$ & $0.7 \pm 0.0^{\mathrm{a}}$ \\
\hline \multicolumn{10}{|l|}{ Sweet } \\
\hline 2006 & $160.0 \pm 0.3^{c}$ & $85.0 \pm 0.2^{\mathrm{b}}$ & $1865.0 \pm 1.3^{\mathrm{c}}$ & $216.0 \pm 0.2^{c}$ & $90.0 \pm 0.3^{b}$ & $4.3 \pm 0.1^{\mathrm{b}}$ & $0.7 \pm 0.1^{\mathrm{b}}$ & $0.8 \pm 0.0^{\mathrm{b}}$ & $0.6 \pm 0.0^{\mathrm{a}}$ \\
\hline 2007 & $171.0 \pm 0.3^{d}$ & $83.0 \pm 0.0^{b}$ & $1934.0 \pm 2.4^{\mathrm{d}}$ & $223.0 \pm 0.2^{c}$ & $87.0 \pm 0.1^{\mathrm{b}}$ & $3.8 \pm 0.1^{b}$ & $0.8 \pm 0.3^{b}$ & $0.7 \pm 0.0^{\mathrm{b}}$ & $0.6 \pm 0.0^{\mathrm{a}}$ \\
\hline \multicolumn{10}{|l|}{ Sour-dried } \\
\hline 2006 & $254.0 \pm 0.1^{\mathrm{e}}$ & $150.0 \pm 0.1^{c}$ & $2416.0 \pm 1.3^{\mathrm{e}}$ & $197.0 \pm 0.2^{\mathrm{d}}$ & $119.0 \pm 0.4^{\mathrm{c}}$ & $2.7 \pm 0.0^{c}$ & $1.5 \pm 0.3^{c}$ & $1.1 \pm 0.0^{c}$ & $0.8 \pm 0.0^{\mathrm{b}}$ \\
\hline 2006 & $251.0 \pm 0.3^{\mathrm{e}}$ & $149.0 \pm 0.8^{\mathrm{c}}$ & $2441.0 \pm 1.1^{\mathrm{e}}$ & $194.0 \pm 0.2^{\mathrm{d}}$ & $120.0 \pm 0.2^{\mathrm{c}}$ & $2.9 \pm 0.0^{c}$ & $1.5 \pm 0.2^{\mathrm{c}}$ & $1.1 \pm 0.0^{c}$ & $0.9 \pm 0.0^{\mathrm{b}}$ \\
\hline
\end{tabular}

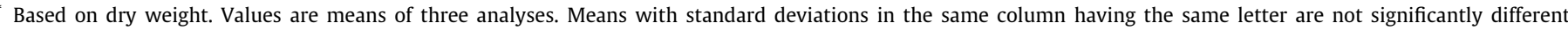
$(p<0.05)$.

(Morton, 1987; Leakey, 1999). The amount of vitamin C in the sweet fruits was comparable to that which was found in grapes (38 mg $100 \mathrm{~g}^{-1}$ ) but less than in oranges (50 mg $100 \mathrm{~g}^{-1}$ ) and strawberries (59 mg $100 \mathrm{~g}^{-1}$ ) (Eromosele, Eromosele, \& Kuzhkuzha, 1991). The sweet fruit vitamin C content $(40.7 \pm 0.0$ and $43.8 \pm 0.0 \mathrm{mg} 100 \mathrm{~g}^{-1}$ ) is also comparable to that of Vitex mombassae (40.4 mg $100 \mathrm{~g}^{-1}$ ) and higher than the values reported for S. birrea, Uakapa kirkiana and A. digitata (20.1, 20.4 and $20.3 \mathrm{mg} 100 \mathrm{~g}^{-1}$, respectively) wild fruits, as reported by Ndabikunze, Masambu, and Tiisekwa (2010). Vitamin C is the primary water soluble antioxidant in the human body, eliminating free radicals and preventing damage in the aqueous environment both inside and outside cells (Pattison et al., 2004).

\subsection{Mineral content of the fruits}

The mineral composition of masau fruit classes based on dry weight are shown in Table 2. Macroelements (Ca, Mg, $\mathrm{K}$, Na and $\mathrm{P}$ ) and microelements ( $\mathrm{Fe}, \mathrm{Cu}, \mathrm{Mn}$ and $\mathrm{Zn}$ ) were analysed. Amongst the macroelements, potassium was the most abundant mineral present in the fruits ranging from $1865 \pm 1.3$ to $2441 \pm$

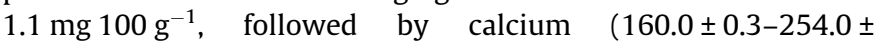

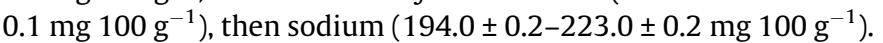
Magnesium and phosphorus were the least abundant mineral elements with values ranging between $83.0 \pm 0.0$ and $150.0 \pm 0.1 \mathrm{mg} 100 \mathrm{~g}^{-1}$. There was significant variation $(p<0.05)$ in the amount of calcium and potassium amongst the years (2006 and 2007) for both sour and sweet fruits. The calcium content of both sweet and sour fruits $(160.0 \pm 0.31$ and

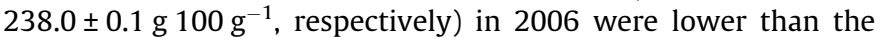

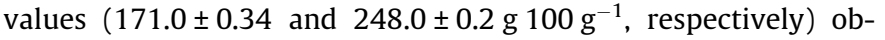
tained in 2007. Nutrient content in the fruits can be influenced from year to year by weather conditions and the local environment (Feyssa, Njoka, Asfaw, \& Nyangito, 2011). However, no variation was observed for the other elements for the two seasons. The con-

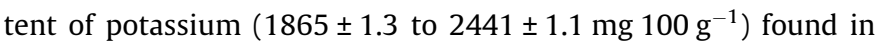
this study is many folds higher that found in fruits, such as guava (417 mg $\left.100 \mathrm{~g}^{-1}\right)$, orange (200 mg $\left.100 \mathrm{~g}^{-1}\right)$, apple (90 mg $100 \mathrm{~g}^{-1}$ ) and banana (358 mg $100 \mathrm{~g}^{-1}$ ) (Mahapatra et al., 2012). Potassium has diverse roles in the human metabolism and body functions and is essential for proper functioning of cells, tissues and organs. The calcium content of sweet fruits $(160 \pm 0.3$ and $171 \pm$ $\left.0.3 \mathrm{mg} 100 \mathrm{~g}^{-1}\right)$ was significantly $(p<0.05)$ lower than that of sour

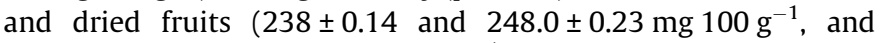
$251.0 \pm 0.3$ and $254 \pm 0.1 \mathrm{mg} 100 \mathrm{~g}^{-1}$, respectively), for the two seasons. Calcium content $\left(160.0 \pm 0.3-254.0 \pm 0.1 \mathrm{mg} 100 \mathrm{~g}^{-1}\right)$ of the masau fruits was also found to be much higher than known

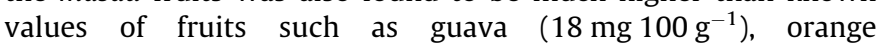

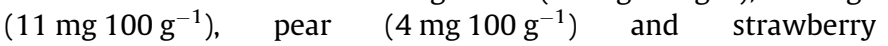

(22 mg $100 \mathrm{~g} \mathrm{~g}^{-1}$ ) as reported by Mahapatra et al. (2012). The sour and dried fruits had higher amounts of magnesium (90 \pm 0.1 and

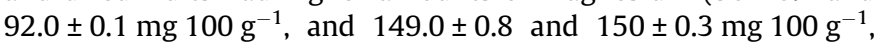
respectively) compared to the sweet fruits $(83 \pm 0.0$ and $85 \pm 0.2 \mathrm{mg} 100 \mathrm{~g} \mathrm{~g}^{-1}$ ), for the two seasons. The range of values $\left(83.0 \pm 0.0-2441.0 \pm 1.1 \mathrm{mg} 100 \mathrm{~g}^{-1}\right)$ of macroelements found in masau fruits in this study for calcium, magnesium, potassium, sodium and phosphorus are much higher than the range of values $\left(1.2 \pm 0.4-175.7 \pm 73.5 \mathrm{mg} 100 \mathrm{~g}^{-1}\right)$ reported by Ndabikunze et al. (2010) for other wild fruits such as V. mombasse, U. kirkiana, $S$. birrea and $A$. digitata. The calcium, magnesium and potassium have essential roles in a variety of body functions including bone health and heart, muscle, nerve and immune systems maintenance.

Regarding the microelements, no variation among samples of the two seasons was observed. Iron was the main element showing highest values $\left(2.1 \pm 0.5-4.3 \pm 0.1 \mathrm{mg} 100 \mathrm{~g}^{-1}\right)$. The sweet fruits had significantly higher amounts of iron $(3.8 \pm 0.1$ and $4.3 \pm$ $\left.0.1 \mathrm{mg} 100 \mathrm{~g}^{-1}\right)$ compared to the sour and dried fruits $(2.1 \pm 0.5-$

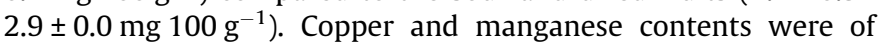
similar ranges $(0.7 \pm 0.1-1.5 \pm 0.3$ and $0.7 \pm 0.0-1.6 \pm$ $0.0 \mathrm{mg} 100 \mathrm{~g}^{-1}$, respectively). Zinc content was the lowest with

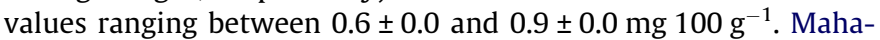
patra et al. (2012) reported lower values for iron $\left(1.04 \mathrm{mg} 100 \mathrm{~g}^{-1}\right)$,

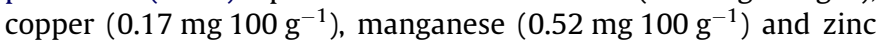

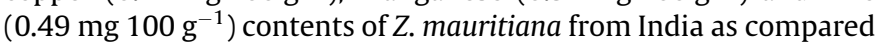
to iron $\left(2.1 \pm 0.5-4.3 \pm 0.1 \mathrm{mg} 100 \mathrm{~g}^{-1}\right)$, copper $(0.7 \pm 0.1-1.5 \pm$ $\left.0.3 \mathrm{mg} 100 \mathrm{~g}^{-1}\right)$, manganese $\left(0.7 \pm 0.03-1.6 \pm 0.03 \mathrm{mg} 100 \mathrm{~g}^{-1}\right)$ and zinc $\left(0.6 \pm 0.0-0.9 \pm 0.0 \mathrm{mg} 100 \mathrm{~g}^{-1}\right)$ contents obtained from the current study. The masau fruit contents of iron $(2.1 \pm 0.5-$

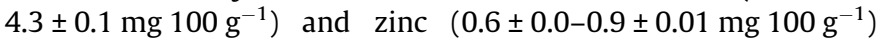
are much higher than the values of iron $\left(0.09-0.11 \mathrm{mg}^{100 \mathrm{~g}^{-1}}\right)$ and zinc $\left(0.02-0.22 \mathrm{mg} 100 \mathrm{~g}^{-1}\right)$ reported by Amerteifio and Mosase (2006) for other wild fruits like A. digitata, S. birrea, S. spinosa and $V$. infausta. The iron content of masau fruits is also higher than the content found in fruits such as mango, orange, grapes, banana and papaya, as reported by Mahapatra et al. (2012). There is, therefore, value in consuming masau fruits when they are available.

\section{Conclusion}

The Z. mauritiana (masau) fruits from the Zambezi valley in Zimbabwe contain nutritionally significant levels of important nutrients including minerals, fibre and crude protein. The sweet masau fruit were found to be richer in vitamin $C$ than the sour fruit, whereas the sour fruit were richer in minerals. The fresh sweet fruits were particularly richer in vitamin $C$ than the sour fruits. However, there was very little variation in nutrient content with season. The results show that the nutrient value of masau wild 
fruits can even be higher than some domesticated popular fruits, such as mango, guava, orange and strawberry in terms of protein, carbohydrates and the micronutrient contents. This makes the fruit a potential contributor towards a balanced diet for children and adolescents in Zimbabwe and surrounding countries, considering their low cost and high abundance. Therefore, consumption of masau fruits needs to be promoted as they can contribute significantly to the diet and income of the rural people of Zimbabwe in the areas where the fruits are found.

\section{Acknowledgements}

The financial support by the MacGillavry Fund of the Royal Netherlands Academy of Arts and Sciences (KNAW) and the International Foundation for Science (IFS Grant No. C/3737) is gratefully acknowledged. The authors thank the technical assistance given by Evan Nyatanga and Power Gombiro.

\section{References}

Amarteifio, J. O., \& Mosase, M. O. (2006). The chemical composition of selected indigenous fruits of Botswana. Journal of Applied Science and Environmental Management, 10, 43-47.

AOAC (1990). Official Methods of Analysis. Arlington, Virginia, USA: Association of Official Analytical Chemists.

Agrahar-Murugkar, D., \& Subbulakshmi, G. (2005). Nutritive values of wild edible fruits, berries, nuts, roots and spices consumed by the Khasi tribes of India. Ecology of Food and Nutrition, 44, 207-233.

Bonire, J. J., Jahil, N. S., \& Lori, J. A. (1990). Sodium and potassium content of two cultivars of white yam (Dioscorea rotundata) and their source soils. Journal of the Science of Food and Agriculture, 53, 271-274.

Eromosele, I. C., Eromosele, C. O., \& Kuzhkuzha, D. M. (1991). Evaluation of mineral elements and ascorbic contents in fruits of some wild plants. Plants Foods for Human Nutrition, 41, 151-154.

Feyssa, D. H., Njoka, J. T., Asfaw, Z., \& Nyangito, M. M. (2011). Wild edible fruits of importance for human nutrition in semi-arid parts of East Shewa Zone, Ethiopia: Associated indigenous knowledge and implications to food security. Pakistan Journal of Nutrition, 10, 40-50.

Lazano-Calero, D., Martin-Palomeque, P. I., \& Madueno-Loriguillo, S. (1996). Phosphorus in cola drinks. Journal of Chemical Education, 73, 1173-1174.

Leakey, R. R. B. (1999). Potential for novel food products from agroforestry trees: A review. Food Chemistry, 66, 1-14.

Lewicki, P. P. (1998). Effect of pre-drying treatment, drying and rehydration on plant tissue properties: A review. International Journal of Food Properties, 1, $1-22$.
Lockett, C., Calvet, C. C., \& Grivetti, L. E. (2000). Energy and micronutrient composition of dietary and medicinal wild plants consumed during drought. Study of rural Fulani, Northeastern Nigeria. International Journal of Food Sciences and Nutrition, 51, 195-208.

Mahapatra, A. K., Mishra, S., Basak, U. C., \& Panda, P. C. (2012). Nutrient analysis of some selected wild edible fruits of deciduous forests of India: An explorative study towards non conventional bio-nutrition. Advanced Journal of Food Science and Technology, 4, 15-21.

Mithofer, D., Waibel, H., \& Akinnifesi, F. K. (2006). The role of food from natural resources in reducing vulnerability to poverty: A case study from Zimbabwe. In Proceedings of the German development economic conference (vol. 28). Berlin: Research Committee Development Economics.

Morton, J. F. (1987). Indian jujube. In J. F. Morton (Ed.), Fruits of Warm Climates, (pp. 272-275). Florida, USA: Miami.

Naggy, S. (1980). Vitamin C contents of citrus fruits and their product: A review. Journal of Agricultural and Food Chemistry, 28, 8-18.

Ndabikunze, B. K., Masambu, B. N., \& Tiisekwa, B. M. (2010). Vitamin C and minera contents, acceptability and shelf life of juice preparation from four indigenous fruits of the Miombo woodlands of Tanzania. Journal of Food, Agriculture and Environment, 8, 91-96.

Nyanga, L. K., Nout, M. J. R., Gadaga, T. H., Boekhout, T., \& Zwietering, M. H. (2008). Traditional processing of masau fruits (Ziziphus mauritiana) in Zimbabwe. Ecology of Food and Nutrition, 47, 95-107.

Nyanga, L. K., Nout, M. J. R., Gadaga, T. H., Theelen, B., Boekhout, T., \& Zwietering, M. H. (2007). Yeasts and lactic acid bacteria microbiota from masau (Ziziphus mauritiana) fruits and their fermented fruit pulp in Zimbabwe. International Journal of Food Microbiology, 120, 159-166.

Osman, M. A. (2004). Chemical and nutrient analysis of baobab (Adansonia digitata) fruit and seed protein solubility. Plants for Human Nutrition, 59, 29-33.

Pattison, D. J., Silman, A. J., Goodson, N. J., Lunt, D., Bunn, R., Luben, A., et al. (2004) Vitamin $C$ and the risk of developing inflammatory polyarthritis, prospective nested case control study. Annals of the Rheumatic Diseases, 63, 843-847.

Paul, G., \& Pearson, W. N. (1967). The vitamins: Chemistry, physiology, pathology, methods (2nd ed., Vol. VI). New York, USA: Academic Press.

Rathore, M. (2009). Nutrient content of important fruit trees from arid zone of Rajasthan. Journal of Horticulture and Forestry, 1, 103-108.

Ruiz-Rodríguez, B., Morales, P., Fernández-Ruiz, V., Sánchez-Mata, M., Cámara, M. Díez-Marqués, C., et al. (2011). Valorization of wild strawberry-tree fruits (Arbutus unedo L.) through nutritional assessment and natural production data Food Research International, 44, 1244-1253.

Saka, K. J. D., \& Msonthi, J. D. (1994). Nutritional value of edible fruits of indigenous wild trees in Malawi. Forest Ecology and Management, 64, 245-248.

Saka, K. J. D., Rapp, I., Akinnifesi, F. K., Ndolo, V., \& Mhango, J. (2007). A comparative study of the physicochemical and organoleptic characteristics of Uapaca kirkiana, Strychnos cocculoides, Adansonia digita and Mangifera indica products. International Journal of Food Science and Technology, 42, 836-841.

Tembo, L., Chiteka, Z. A., Kadzere, I., Akinnifesi, F. K. \& Tagwira, F. (2008). Storage temperature affects fruit quality attributes of Ber (Ziziphus mauritiana Lamk.) in Zimbabwe. African Journal of Biotechnology, 7, 3092-3099. 